\title{
DIFFERENTIATION, SELF-SELECTION AND REVENUE MANAGEMENT
}

\author{
Irene C L Ng ${ }^{1}$, Ph.D.
}

Manuscript submitted to THE JOURNAL OF REVENUE AND PRICING MANAGEMENT

July 21, 2005

\footnotetext{
${ }^{1}$ Dr. Irene C L Ng is with the School of Business and Economics, University of Exeter, U.K. She is also the Group Vice Chairman of SA Tours Group of Companies, a regional tour operator based in Malaysia, Singapore and China, as well as the Chairman of C L Ng \& Associates (Malaysia and Hong Kong), a strategy consulting firm.

Contact Information: School of Business and Economics, University of Exeter, Streatham Court, Rennes Drive, Exeter EX4 4PU, United Kingdom Tel: +44 (0) 1392 263250, Fax: +44 (0) 1392 263242, Email: Irene.ng@exeter.ac.uk
} 


\title{
DIFFERENTIATION, SELF-SELECTION AND REVENUE MANAGEMENT
}

\begin{abstract}
This paper takes an interdisciplinary approach towards revenue management, incorporating economics and marketing concepts and proposing that firms employ a dynamic service differentiation so that consumer needs are met more closely. To locate market segments, the paper proposes that firms employ segmentation based on selfselection, providing consumers with an array of choices that are truth revealing and allowing firms to price discriminate without the need to predetermine segments. Through differentiation and self selection, uncertainty could also be reduced. Furthermore, self selection could also allow firms to reduce the costs of coordinating and monitoring rate fences.
\end{abstract}

Key Words: Product Differentiation, Market Segmentation, Self-Selection, Revenue Management 


\section{DIFFERENTIATION, SELF-SELECTION AND REVENUE MANAGEMENT}

\section{INTRODUCTION}

Revenue management is the practice of obtaining the highest possible revenue in the selling of a service firm's capacity. Essentially, buyers of a service purchase at different times before the consumption of the service. Hence, the firm would charge different prices according to buyers' purchase times. Moreover, it is imperative that capacity sold to earlier (and perhaps lower paying) customers would not deprive the firm of obtaining higher revenue from customers arriving later. Consequently, firms would attempt to forecast demand and use tools such as targeted pricing and market segmentation to ensure the limited capacity of the firm attains the highest possible revenue. This practice is starting to find favor with many service firms that face relatively fixed capacity e.g. restaurants, hotels, cruise lines, electric power supply, and railways (Bitran and Caldentey, 2003).

In this paper, I provide an interdisciplinary approach towards revenue management, incorporating economics and marketing concepts and proposing that firms could take on a more proactive approach towards reducing uncertainty. I suggest that service firms could employ a dynamic service differentiation so that consumer needs are met more closely. However, differentiation is necessary but not sufficient to improve revenues. Firms must also be able to target the segments with differential pricing. Since consumer segments may not be easily discernible, firms could employ segmentation based on self-selection, providing consumers with an array of choices that are truth revealing and allowing firms to price discriminate without the need to predetermine market segments. Self selecting market segmentation could also allow firms to reduce the costs of coordinating and monitoring rate fences. Through a combination of differentiation and self selection, firms therefore have another option to reduce uncertainty instead of forecasting demand.

\section{MANAGING DEMAND VERSUS INFLUENCING DEMAND}

One of the key principles of revenue management lies in the firm's ability to forecast demand (Jauncey et al., 1995, Pak and Piersma, 2002, Kimes, 1999, 2003). Revenue management systems must be able to advise on demand conditions by analyzing reservation patterns, arrival, departures and a score of other demand characteristics (Jauncey et al., 1995, Donaghy et al., 1995, 1997). Recent literature has suggested that revenue management systems with demand forecasting algorithms are increasingly expensive to implement, both in real terms and in lost opportunities (Anderson and Blair, 2004, Desiraju and Shugan, 1999). A typical system costs between USD\$1 million to \$3 million and takes more than two years to implement (Lahoti, 2002). Moreover, research has suggested that these complex and sophisticated revenue management systems are not infallible. With demand forecasts using the data of the past and sales departments using present day information, conflicts often occur ( $\mathrm{Ng}$ et al., 1999) and many revenue management systems operate with some level of human intervention, often using these systems as a guide.

Demand forecasting may not be very effective for four reasons. First, demand characteristics, upon which revenue management studies are premised, should be based on fundamental concepts of consumer behavior (cf. Chase, 1999; Lieberman, 1993; 
Relihan, 1989; Boyd, 2004; Desiraju and Shugan, 1999). Within a historical pattern of demand, why consumers behave the way they do are just as important as how they are behaving $(\mathrm{Ng}, 2004)$. Consequently, mere observation of the past may not be a good indicator of the future, as Cary (2004) has also noted. Second, demand forecasting, at its best, is still an aggregation of multiple segments that could, if possible, be desegregated for higher revenue. Third, past demand profiles are subject to many factors, not least the actions and pricing strategies of the competitors at that time, and the firm's own reaction to them. To assume that demand based on historical data can still hold for the future could be assuming too much. Finally, demand can be influenced, not merely be known. As early as 1951, Schumpeter said that wants cannot be taken as independent and consumers could be taught by producers to want new things, "or things which differ in some respect or other from those which they have been in the habit of using" (Schumpeter, 1951; Liebhafsky, 1968).

\section{DYNAMIC SERVICE DIFFERENTIATION}

Indeed, firms have been attempting to influence demand since the beginning of trade, through product differentiation. Smith (1956) described product differentiation as a way to alter the shape of the price-quantity demand curve facing the firm. Differentiation was investigated by various early economics researchers, notably Hotelling (1929) and Chamberlin (1965). Hotelling showed how firms choose their 'locations' in the product space so as to buffer themselves from direct price competition. Chamberlin proposed that consumer perceptions of similar products differ, and whether the perceptions are real or imagined, such preferences led to different demand curves and could be a basis of firms' attempts to differentiate between their products and those of the competitor. Porter (1976), who popularized the notion of product differentiation, elaborated on the practice further, demonstrating that greater revenues can be obtained from differentiation as it increases cross-price inelasticities with respect to competing products. Since then, much of the benefits of product differentiation has been extolled and studied by numerous researchers in both economics and marketing streams.

At the heart of a product differentiation strategy lays consumer value. Firms are able to increase revenue from introducing differentiated products primarily because these products can be distinguished from their rivals on attributes that are "meaningful, relevant and valuable" to consumers (Carpenter et. al., 1994, p 339). However, the concept of value for services is usually more complex. This is because for some services such as a flight or a night's stay at a hotel, the consumption of a service, commonly labeled as the service experience, lasts a meaningful length of time (Lovelock and Wirtz, 2003) and is subjected to various influences. Consequently, the value attained by the consumer is multi-attribute, incorporating both the core service (e.g. one night's sleep) as well as the supplementary services (e.g. check-in, facilities etc.). Indeed, service literature has long acknowledged that consumers of services often are willing to pay for service augmentation such as supplemental services that complement and facilitate the core service (Shostack, 1981; Storey and Easingwood, 1998). Lovelock and Wirtz (2003) classified supplemental services into eight categories of information, payment, billing, consultation, order-taking, hospitality, safekeeping and exceptions. 
With an augmented service experience that is multi-attribute in nature, it is therefore logical to conceive that a heterogeneous market of consumers would value such attributes differently and would be willing to pay different prices according to the different levels of service attained e.g. business class vs economy class.

As many service firms operate with high fixed and low marginal costs, certain aspects of the augmented service can therefore be varied without much increase in costs e.g. different channels of payment, in-room check-in etc. Yet, simple variations in service delivery can sometimes lead to higher willingness to pay by consumers, e.g. consumers may be willing to pay higher prices if they don't have to wait.

The point of this discussion is that while it has been acknowledged that differentiation is able to influence demand, the practice of differentiation is traditionally viewed as one that is both strategic and static. The firm decides on the attributes that are important to consumers, produces the product according to what has been specified, and prices according to the (differentiated) demand that unfolds. This is because changing attributes to influence demand dynamically for goods may be too costly or impossible to achieve. Clearly, this may not be true for services. Consequently, the service consumer's willingness-to-pay could be influenced through the firm's manipulation of its augmented service attributes, since marginal costs may be low in producing different variations of the service and the corresponding marginal increase in consumers' willingness-to-pay is high. With current technological advances, such service differentiation practices are becoming increasingly easy and dynamic (Prabhaker et. al, 1995; Kannan and Kopalle, 2001). Accordingly, selling on the internet may be effective not only because it is a low cost channel for firms (cf. Boyd, 2004) but also because it lowers the effort costs of consumers, who may be willing to pay higher for purchases through the internet.

In fact, the very act of requiring consumers to be present in the consumption of a service would already guarantee that the service consumed is a differentiated one. It is widely recognized that services are inconsistently produced (heterogeneous). Hence, it is logical that the consumption of the same service by two customers will be perceived differently, even without the firm's effort to differentiate. In addition, by having to show up to consume, the price heterogeneous consumers pay for a service is not the only cost borne by them. Non-monetary costs (such as effort) expended by the consumer during both purchase and consumption influences the consumer's valuation of the service (Lovelock and Wirtz, 2003). Hence, even if all consumers buy at the same price, the final 'price' paid is different across consumers since they have different time and effort costs.

Moreover, services are experiential products, and often a simple change can alter the value perceptions of consumers. Hence, when services are able to change its attributes relatively easy, assisted by technology, customization strategies result in the firm's ability to dynamically (and almost instantly) modify its service offering in response to the consumers' demands. For example, consumers may be willing to purchase a ticket at a higher price if the ticket can be made more flexible in terms of the time of travel ('open' ticket). Yet the marginal cost of providing flexibility (i.e. differentiation) could be lower than the marginal increase in revenue due to a higher valuation by the consumer. In other words, firms have another avenue to improve revenues i.e. changing consumers' perception of value so that a higher price can be obtained. 


\section{SELF SELECTION AND DYNAMIC MARKET SEGMENTATION}

Merely being able to differentiate does not entitle a firm to higher revenues. To do so, the firm must be able to segment based on its differentiating efforts and target the segments to obtain discriminating prices. How, then does a firm know how to segment consumers and how is the firm to know which consumer segments have a preference for what type of attributes?

This question is also a crucial one in revenue management as one of the prerequisites of revenue management practice is the ability to segment the market (Weatherford and Bodily, 1992; Upchurch et al., 2002; Kimes, 1989; Lieberman, 1993; Schwartz, 1998). Only when the market can be segmented could it be targeted with different prices. Yet, much of the consumer market today is unpredictable. Merely 20 years ago, certain behaviors were often positively correlated with certain lifestyles, ages, income or even geographical location. In other words, the young behaved young, the old behaved old, people with money spent more, families had a father and mother and so on. Today, the old act young and vice versa, people with less money tend to spend more (as credit card debts attest to), and many families have only one parent. With globalization, even cultural behaviors and lifestyle attributes are becoming more complex. As a popular saying goes, "you know you are in a changing world when the top rap artist is Caucasian, the top golfer is African-American and the French call the US arrogant ${ }^{2}$. Faced with such changing times, traditional segmentation through geographic, demographic and even some psycho-graphic approaches are proving to be less effective in predicting purchasing behavior. Even when sophisticated data-sensitive software is used, many market segmentation schemes are not very successful (Neal and Wurst, 2001). It seems ironic that in a world where so much information can be obtained, marketers are becoming less able to understand their customers.

Increasingly, firms lean towards the practice of benefit segmentation (cf. Weinstein, 1987). Benefit segmentation is widely acknowledged as one of the best ways to segment markets as it divides a heterogeneous population into relatively homogeneous groups on the basis of product or service benefits consumers perceive as important (Chang and Chen, 1995).

Yet, when consumers are less predictable, so would their valuation of the attributes within a service. Hence, even when employing benefit segmentation, firms are still left trying to predict which groups of consumers would benefit from which types of service attributes. Consequently, it may not be commercially prudent to tailor a service towards only pre-determined segments. In this respect, a menu of services with flexible attributes allows the market to self select. This idea of segmentation through selfselection was originated from the economics concept of a 'designed contract' for compensating an agent who possesses more information than the agent who offers the contract. By choosing a contract the agent with more information reveals the truth about her/his preference. In marketing, this 'designed contract' can be deemed to be a produce-price pair and the product-price line as an array of contracts offered by the firm who does not know the identity of the consumers in her/his market (Moorthy, 1984). From the array, consumers choose to buy different pairs, thus revealing what they truly

\footnotetext{
${ }^{2}$ Adapted from www.ezboard.com discussion board posting
} 
value. This concept was proposed by the Nobel Laureates of Economics (2001) i.e. Akerlof (1970), Rothschild and Stiglitz (1976) and Spence (1973) as asymmetric information and developed for market segmentation purposes by Moorthy (1984). In application to revenue management it is therefore clear that service choices (i.e. a service that is differentiated on several dimensions), if cleverly designed, are able to separate markets to the degree that traditional segmentation approaches could never have achieved.

Furthermore, traditional revenue management tends to rely on market segmentation practices that may not be efficient, resulting in cannibalization between segments. 'Rate fences', as it is commonly known in revenue management literature becomes more common to reduce such cannibalization. Yet, erecting such fences may result in perceived unfairness (Kimes and Wirtz, 2002; Kimes, 1994). Furthermore, such segmentation efforts would result in increased monitoring and coordinating costs. By adopting an approach of changing the attributes of a service, or providing a menu of service attribute choices, consumers would self-select as all product/service choices are accessible to all segments.

In the earlier example, a simple matter of changing a fixed time ticket to allow flexible consumption times immediately reduces the risk of not being able to consume a service as buyers are not constrained on when they are allowed to travel. Since the choice of ideal travel time is known only to the individual (and therefore is private information because it is not known to the firm) different degrees of flexibility at different prices allow consumers to self select, and this could help to increase revenues. In other words, by tweaking service attributes, the firm can better meet the needs of different consumers.

All this means that although the ability to segment is a necessary element to be able to practice revenue management, the segmentation does not have to be performed by the firm. With an increasing amount of data available about customers, firms could provide a menu of choices that could be less costly than the traditional costs of targeting, coordinating and erecting rate fences.

How does a firm design products that could result in segmentation through selfselection? Three principles need to be followed. First, there must be sufficient incentives within each product for market segments to separate on their own. This means that the attributes that differentiate between segments must be clear. This could be obtained through various means e.g. a conjoint analysis of the market where preferences and trade offs between one attribute and another can be discerned. Second, for two different segments to choose different products, care must be taken such that it is not in the interest of either segment to mimic the behavior of the other segment. For example, in a ski resort, vacationers may know that they could get a lower price of a grocery product if they were to get a local newspaper and cut out a coupon, but may not be willing to do so because it requires effort and they are already willing to pay higher prices. Locals, however, would still continue to enjoy lower prices in this manner. In this way, the firm is able to obtain more optimal revenue instead of having to choose which segment to target. Finally, the array of products presented must be in such a way that each consumer's choice is truth revealing. Consumers choosing one product over another inform the firm which segment they belong to. 
The benefit of such a policy extends beyond the cost savings the firm would enjoy. When consumers self select, they also enable the firm to price discriminate and obtain higher revenues. The Robinson-Patman Act (U.S.) specifies that a firm cannot deny a segment access to what is being offered to another segment, unless legally allowed to do so. Through self-selection, all product choices are available to all segments, yet each segment willingly pays a different price because they have no interest in mimicking the other segment.

Set against this backdrop, it is easy to see the implicit assumptions of demand forecasting. Demand forecasting views the product/service as static, and would aim to predict customers' arrival times. The firm sets prices and capacity allocations based on such forecasted patterns of demand so that capacity allocated to earlier (and perhaps lower paying) customers would not deprive the firm of obtaining higher revenue from customers arriving later. However, my thesis here is that neither price changing nor capacity allocating are the limits of revenue management. As discussed previously, while goods' attributes are far more difficult to change, many service attributes can be changed easily and dynamically because such services can be purchased and consumed by a customer in many different ways. Hence, a more satisfying approach may lie in creating a dynamic system where service attributes could be changed to suit individual segments. By differentiating on a service through technology, mass market becomes more fragmented and segmentable which allows the firm to practice mass customization and targeted pricing to derive higher price discriminating revenues. As Talluri and van Ryzin (2004) proposed, consumer demand is dependent on the controls being applied by the seller. Yet, these controls are not limited to price. Service attributes in themselves could be subjected to change, and in doing so, demand may be influenced.

For example, a key uncertainty in revenue management is having to forecast for 'late arrivals' since this segment is willing to pay a higher price and therefore potentially increase revenues. Rather than forecasting and waiting for buyers to arrive, the firm could allow a flexible flight time (e.g. open tickets) which could in turn persuade the late arrival market to buy earlier as well as pay higher, reducing uncertainty for both the firm and the buyer (buyers could also suffer the uncertainty of not having the service as capacity could have been sold out if they decide to buy too late). Clearly this is a rather simplistic example. However, my point is that revenue managers, instead of merely observing patterns of historical demand, need to understand the antecedents of such demand so that service attributes can be dynamically varied to meet segment needs at more precise levels. In the words of Prabhaker et al. (1995), "at the aggregate level, therefore, the hit rate improves as market uncertainty, measured as the distance between customers' needs and their perceptions of product value, decreases."

This implies that within revenue management at least, conventional demand forecasting is not the only tool to the reduce uncertainty. With the possibility of differentiation without the usual costs associated with it, dynamic service differentiation can be a strategy to reduce uncertainty by pro-actively influencing the distribution of demand through varying its service attributes. Finally, since the firm now has another option to manage uncertainty, it should weigh the cost of installing demand forecasting systems against the cost of allowing more dynamic changes in service attributes.

\section{SUMMARY AND CONCLUSION}


In this paper, I propose two strategies to assist firms in improving revenues and reducing uncertainty, dynamic service differentiation and self selection. Through dynamic service differentiation, service attributes are changed dynamically according to the preferences of consumers, thereby influencing demand and its distribution. This is in contrast to demand forecasting, a practice in revenue management that assumes a static product/service. To discern consumer preferences, the paper proposes self-selection segmentation, whereby all product choices are accessible to all segments, yet each segment willingly pays a different price because they have no interest in mimicking the other segment. By allowing the market to self select, the firm is able to be more precise in segmentation and therefore derive higher revenues. In addition, a self selection strategy could reduce monitoring and coordinating rate fences.

In this information age it is an accepted belief that the success and survival of companies and even individuals are dependent on their ability to "locate and analyze and use information skillfully and appropriately" (Hubbard, 1987). In this respect, information attained by the firm has a dual role. On one hand, it helps the firm seek out customers location (even in the spatial sense), to communicate, promote or sell to them. On the other hand, the firm must also be prepared to look inwards by modifying the service, bundle and construct choices. In so doing, the function of revenue management would be one of improvement and enhancement of revenues, instead of merely managing them. 


\section{REFERENCE}

Akerlof, G. (1970) 'The Market for Lemons: Quality Uncertainty and the Market Mechanism', Quarterly Journal of Economic, Vol. 84, No. 3, pp488-500.

Anderson, C. K., M. Blair.(2004) 'Performance Monitor: The Opportunity Costs of Revenue Management', Journal of Revenue and Pricing Management, Vol. 2 No. 4, pp353-367.

Boyd, E. A. (2004), 'Dramatic Changes in Distribution will Require Renewed Focus on Pricing and Revenue Management Models,' Journal of Revenue and Pricing Management, Vol. 3, No. 1, pp100-103.

Bitran, G., R. Caldentey (2003), 'An Overview of Pricing Models for Revenue Management', Manufacturing and Service Operations Management, Vol. 5, No. 3, pp203-229.

Carpenter, Gregory S., Rashi Glazer and Kent Nakamoto (1994), 'Meaningful Brands from Meaningless Differentiation: The Dependence on Irrelevant Attributes,' Journal of Marketing Research, Vol. 31, No. 3, pp339-350

Cary, D. (2004) 'A view from the inside', Journal of Revenue and Pricing Management, Vol. 3, No. 2, pp200-203(4).

Chase Jr., C. W. (1999), 'Revenue Management: A Review,' Journal of Business Forecasting Methods and Systems, Vol. 18, No. 2, 2 and 28.

Chang, Tung-Zong and Su-Jane Chen (1995), 'Benefit segmentation: A useful tool for financial investment services,' Journal of Professional Services Marketing, Vol. 12, No. 2, pp69-77

Chamberlin Edward H. (1965) The Theory of Monopolistic Competition, Cambridge, MA: Harvard University Press

Dickson, P R \& Ginter (1987), 'Market Segmentation, Product Differentiation and Marketing Strategy', Journal of Marketing, Vol. 51, pp1-10

Desiraju, R., . M. Shugan (1999), 'Strategic Service Pricing and Yield Management', Journal of Marketing, Vol. 63, pp44-56

Donaghy, K., U. McMahon D. McDowell. (1995), 'Yield Management: An Overview', International Journal of Hospitality Management, Vol. 14, No. 2, pp139-150 
Donaghy, K., U. McMahon D. McDowell. (1997), 'Implementing Yield Management: Lesson from the Hotel Sector', International Journal of Contemporary Hospitality Management, Vol. 9, No. 2, pp50-54.

Gronroos C. (1990), Service Management and Marketing: Managing the Moments of Truth in Service Competition, Lexington, Lexington Books

Hubbard, Susan. (1987), Information Skills for an Information Society: A Review of Research, ERIC Clearinghouse on Information Resources, Syracuse, NY

Hotelling H (1929), 'Stability in competition', Economic Journal, Vol. 39, pp41-57

Jauncey, S., I. Mitchell, P. Slamet. (1995), 'The Meaning and Management of Yield in Hotels', International Journal of Contemporary Hospitality Management, Vol. 7, No. 4, pp23-26

Kannan, P. K., P. K. Kopalle (2001), 'Dynamic Pricing on the Internet: Importance and Implications for Consumer Behavior', International Journal of Electronic Commerce, Vol. 5, pp63-84

Kimes, S.E. (1989), 'Yield Management: A Tool for Capacity Constrained Service Firms', Journal Of Operations Mgmt, Vol. 8, pp348-363.

Kimes, S.E. (1999), 'Group Forecasting Accuracy in Hotels', Journal of the Operational Research Society, Vol. 50, pp1104-1110

Kimes, S.E. (1994), 'Perceived Fairness of Yield Management,' Cornell Hotel and Restaurant Administration Quarterly, Vol. 35, No. 1, pp22-29

Kimes, S. E. (2003), 'Revenue Management: A Retrospective', Cornell Hotel and Restaurant Administration Quarterly, Vol. 30, No. 3, pp14-19

Kimes, S.E. and Jochen Wirtz (2002), 'Perceived Fairness of Demand Based Pricing for Restaurants", Cornell Hotel and Restaurant Administration Quarterly

Lahoti, A. (2002), 'Why CEOs Should Care About Revenue Management: How to minimize the implementation pains and maximize the benefits', OR/MS Today, February, (accessed on 27 May 2005), [available at http://www.lionhrtpub.com/orms/orms-2-02/frrm.html]

Lederer, P., I. Yeoman. (2003), 'The Natural Extension of Marketing', Journal of Revenue and Pricing Management, Vol. 2, No. 1, pp81-82.

Lieberman, W. H. (1993), 'Debunking the Myths of Yield Management', Cornell Hotel and Restaurant Administration Quarterly, 34-41. 
Liebhafsky, H.H. (1968), The Nature of Price Theory (Revised Edition), The Dorsey Press, Inc., Homewood.

Lovelock, C., and J. Wirtz. (2003), Services Marketing: People, Technology, Strategy, $5^{\text {th }}$ edition, Prentice Hall.

Moorthy, K. S. (1984), 'Market Segmentation, Self-Selection, and Product Line Design', Marketing Science, Vol. 3, No. 4, pp288-307

Murray, K.B., and J.L. Schlachter. (1990), 'The Impact of Services versus Goods on Consumers' Assessment of Perceived Risk and Variability'. Journal of the Academy of Marketing Science, Vol. 18, pp51-65

Neal, William D. and John Wurst (2001), Advances in Market Segmentation, Marketing Research. A Magazine of Management and Applications, Spring

Ng, I. C. L, J. Wirtz and K. S. Lee. (1999), 'The Strategic Role of Unused Service Capacity', International Journal Of Service Industry Management, Vol. 10, No. 2, pp211-238.

Pak, K., N. Piersma. (2002), 'Overview of OR Techniques for Airline Revenue Management,' Statistica Neerlandica, Vol. 56, No. 4, pp479-495

Porter, M. (1976), Interbrand Choice, Strategy and Bilateral Market Power, Cambridge, MA: Harvard University Press

Prabhaker, P. R. Joel, D. Goldhar, D. Lei. (1995), 'Marketing Implications of Newer Manufacturing Technologies', Journal of Business and Industrial Marketing, Vol. 10, No. 2, pp48-58.

Relihan III, J. Walter. (1989), 'The Yield Management Approach to Hotel-Room Pricing', Cornell Hotel and Restaurant Administration Quarterly. pp40-45.

Rothschild M., and J. Stiglitz. (1976), 'Equilibrium in Competitive Insurance Markets: An Essay on the Economics of Imperfect Information', Quarterly Journal of Economics, Vol. 90, pp629-649.

Schumpeter, J. A. (1951), 'Economic Theory and Entrepreneurial History', in R. V. Clemence, ed., Essays on Economic Topics of Joseph Schumpeter. Port Washington, NY: Kennikat Press.

Schwartz, Z. (1998), 'The Confusing Side of Yield Management: Myths, Error and Misconception', Journal of Hospitality and Tourism Research, Vol. 22, No. 4, pp413-430 
Shostack, G.I. (1981), 'How to design a Service' in Marketing of Services J.H., Donnelly and W.R. George (eds), Chicago: American Marketing Association, pp221-229

Smith, Wendell (1956), 'Product Differentiation and Market Segmentation as Alternate Marketing Strategies,' Journal of Marketing, Vol. 21, pp3-8

Spence M. (1973), 'Job Market Signaling', Quarterly Journal of Economics, Vol. 87, pp355-374.

Storey, Chris and Christopher J. Easingwood (1998), 'The Augmented Service Offering: A Conecptualization and Study of its Impact on New Service Success,' Journal of Product Innovation Management, Vol. 15, pp335-351

Talluri, K., G. van Ryzin. (2004), 'Revenue Management Under a General Discrete Choice Model of Consumer Behavior', Management Science, Vol. 50, pp15-33.

Upchurch, R. S., T. Ellis, and J. Seo (2002), 'Revenue Management underpinnings: An Exploratory Review', Hospitality Management, Vol. 21, pp67-83

Weatherford, L. R., and S. E. Bodily. (1992), 'A Taxonomy and Research Overview of Perishable-Asset Revenue Management: Yield Management, Overbooking, and Pricing', Operations Research, Vol. 40, pp831-844.

Weinstein, A. (1987), Market Segmentation, Chicago, Illinois 